\title{
Figurative Language and Stylistic Function in J. P. Clark-Bekederemo's Poetry
}

\author{
Ebi Yeibo \\ Dept of English \& Literary Studies, Faculty of Arts, Niger Delta University, Wilberforce Island, Bayelsa State, Nigeria \\ Email: eyeibo@gmail.com
}

\begin{abstract}
Earlier studies on J.P Clark-Bekederemo's poetry have concentrated on literary and some linguistic features, highlighting the relation of theme and figuration in the works. However, such studies have paid little attention to the role figurative language plays in foregrounding stylistic functions in the texts, which is very crucial for a comprehensive description and interpretation of the poet's idiolect. This study, therefore, investigates the stylistic value of figuration as semantic signifiers or reinforcers in the poetry. Specifically, with M.A.K. Halliday's three metafunctions of language viz: ideational, interpersonal, and textual, as the analytical model, the study examines the use of figurative devices such as imagery, metaphorization, rhetorical operations, humour, and figures of sound, to foreground aspects of meaning in the texts, in relation to context of situation and textual function. The study posits that any serious stylistic exploration of J.P ClarkBekederemos poetry and poetry in general, must foreground the role figurations play in conveying textual messages and producing aesthetic effects.
\end{abstract}

Index Terms-J. P. Clark-Bekederemo, poetry, figurative language, stylistic function

\section{INTRODUCTION}

The role played by figurative language in encoding the meaning of a literary text cannot be over emphasized. Specifically, it serves both functional and artistic purposes. This infers that, figurative language acts as semantic signifiers in texts and also helps the literary artist in achieving beauty in form.

The critical fact that emerges from the foregoing is that, figurative language constitutes the cornerstone of the literariness or ornamental nature of literary language, as it enables the writer to exploit and manipulate the latent potentials of language, in sundry ways, for specific stylistic effects. Importantly, this pattern of language use is more predominant in poetry than other genres of literature (i.e. drama and prose). Balogun (1996) avers that,

What distinguishes poetry from the other two major genres ...is the emphasis it places on the imaginative use of language... it is the common practice of the poet to use words figuratively and hence the proliferation of figures of speech, collectively called imagery, in poetry (p.349-350).

Ogunsiji (2000) adds that, figurative language is “... a form of picture language" (p.56). The implication of this viewpoint is that, figurations do not only decorate poems and endow them with aesthetic value, they also convey connotative meanings and produce certain special effects, which enrich the texts and make their meanings more precise and concrete. According to Balogun (1996), this fact explains why, in poetry, “... we predominantly look beyond the ordinary denotative meaning of the language to its connotative or implied meaning" (p.349).

The present study, therefore, adds to the corpus of works on J.P. Clark-Bekederemo's poetry, by investigating the role played by figurative language in producing the desired meanings and aesthetic effects in the poetry.

\section{LITERATURE REVIEW / THEORETICAL FOUNDATIONS}

Stylistics is the branch of general linguistics which focuses on style (i.e. the specific way a particular writer or speaker expresses himself), particularly in works of literature. According to Cluett and Kampeas (1979), it is the judgment of the tangible manifestation of style.

Over the years various theories have been propounded by different scholars, to explicate the concept of language and its use, particularly in literary circles. This fact underscores the critical place of language in human existence, as it constitutes the bedrock of human socialization and civilization. The Russian formalism of the 1920s and the structuralism school of the 1960s, postulate the existence of a special "poetic language", as distinct from "ordinary" or "scientific" language. Wellek and Warren (1963) also distinguishes a poetic use of language, in the sense that, it is nonreferential, non-practical, non-casual, etc (p.22-26). This implies that "poetic language" is unique as a result of its conscious use of linguistic and imagistic devices to foreground aspects of meaning.

Another fundamental aspect of the language of poetry is its deviant character. The language of poetry inherently and overtly deviates from linguistic conventions or norms, at all levels of its use i.e. semantic, phonological, lexical, syntactic, etc. According to Crystal (1987), it is this deviant and abnormal feature of the language of poetry that stylistics focuses on (p.71). Chomsky's Transformational Generative Grammar (TGG), is also germane to the present 
discourse, as it postulates the disparity and relations between deep and surface structures. The point is that the meaning of surface linguistic constructs like poetry is retrievable only in the deep structure.

However, since the primary concern of the present study is on the functional aspect of language, we shall adopt M. A K. Halliday's Systemic Functional Grammar (SFG), as our analytical model, in the sense that it focuses not only on the structure of language, but also on the properties of discourse and its functions in specific social and cultural situations. Specifically, the study adopts Halliday's three multifunctions of language viz: ideational, interpersonal, and textual for the textual analysis. The ideational metafunction focuses on the subject matter or field of discourse, while the interpersonal metafunction refers to the tenor of discourse i.e. the social relationship that exists among participants in a given discourse situation, which has the potentials to influence or shape language use. The textual metafunction is particularly relevant to our study, as it focuses on the internal organization and communicative nature of a text. The preoccupation of this study is to show how figurative language is organized in J.P. Clark-Bekederemo's poetry, to foreground aspects of meaning and aesthetics in the texts.

The language of African literature has its socio-cultural peculiarities. The historical fact of colonialism, which made countries in the continent ether Anglophone or Francophone, etc, has made the imperialist languages the media of literary expression. However, African writers have devised various strategies to contextualize indigenous meaning in these imperialist languages. Adejare (1992) avers that traces of African mother tongue are most pronounced in the works of African writers. Alo (1998) summarized these "traces" or peculiar linguistic characteristics of the literature viz: coinages, borrowings, native similes and metaphors, native rhetorical devices, transliteration, native proverbs and idioms, etc. As the textual analysis in this study demonstrates, J.P Clark-Bekederemo's idiolect exhibits aspects of these interlingual features.

The dominant critical focus on African poetry has been on the traditional literary and thematic features of texts. Linguistic/stylistic studies are generally sparse (see Eyoh, 1997). The few works that attempt a linguistic/stylistic appraisal of poetic creations in the continent include: Anozie's (1985) "Equivalent Structures in Soyinka's Poetry: Toward a Linguistic Methodology in African Poetry Criticism," Ofuani's (1987) A Stylistic Analysis of Okot P'Bitek's Poetry, Osakwe's (1992) The Language of Wole Soyinka's Poetry: A Diatype of English, Adejare's (1992) Language and Style in Soyinka: A Systemic Textlinguistic Study of a Literary Idiolect, Eyoh's (1997) J.P Clark-Bekederemo's Poetry: A Study in Stylistic Criticism, Edonmi's (2000) A Text-Linguistic Enquiry into Osundare's Poetic Idiolect, and Ushie's (2001) Many Voices,, Many Visions: A Stylistic Study of 'New' Nigerian Poetry.

Importantly, from the corpus of available literature, J.P Clark-Bekederemo's poetry has not been given intensive linguistic enquiry like other African poets, such as Soyinka and Osundare. In fact, Eyoh's (1997) J.P. ClarkBekederemo's Poetry: A Study in Stylistic Criticism remains the only full-scale work that applies linguistic insights and methods to the study of the poet. However this work is limited by its triadic focus on phonostylistics, diction, and animal symbolism. Although the scholar explores aspects of figures of sound (i.e alliteration, rhyme, repetition), it is in relation to the "fast and lively" African musical rhythm. The scholar posits that African musical rhythm in ClarkBekederemo's poetry is realized principally through these three phonostylistic devices.

\section{The Concepts of Figurative Language and Stylistic Function}

According to Ogunsiji (2000), Language may be said to work in two broad dimensions namely literal and figurative dimensions. The literal dimension of language use deploys words in their usual and obvious sense without any additional suggestions. On the other hand, the figurative dimension deals with the suggestive or connotative use of language (p.56).

Figuration, therefore, implies extended or associative meanings i.e. the use of language in an imaginative manner, to elaborate a thesis or proposition and also to appeal to the emotions of the reader or listener. Ogbulogo (2005) explains:

Literature as an aspect of communication expresses meaning. Incidentally, the language of literature is coded in a creative way, using figures of speech. The meaning deriving from figures of speech is not the meaning of the different components of the expressions. Thus, figures of speech require special attention and explication (p.73).

As we have earlier observed, figuration is a critical consideration or element to the composition of poetry texts, in the sense that, it helps the poet to economize words and, at the same time, make his works picturesque, concrete and adequate. According to Ogbulogo (2005), in semantics, figures of speech help writers to extend the meaning of concepts or phenomena, resulting in polysemy or transfer of senses. Thus, figurative language is often perceived to be metaphoric. The scholar adds that, figurative language covers different devices which are semantically or grammatically marked or unusual. Balogun (1996) corroborates this view when he averred that, the “... consequence of the poet's imaginative approach to language is that in poetry everyday words and expressions often acquire new meanings" (p.349). Hence Ogunsiji (2000) avers that, "if one writes without using figures of speech, one's speech or writing will be "dry" (p.56). Figurations include: simile, metaphor, personification, alliteration, assonance, paradox, oxymoron, etc.

Stylistic function, on the other hand, is an aspect of language function. According to Alo (1998), language function can be explained in two ways. Firstly, it refers to the specific use to which a writer or speaker puts the language (i.e. description, explanation, argument, persuasion, humour etc). Secondly, in stylistic description it refers to the communicative value or role of specific language categories (i.e. sentence, clause, word group, collocations, word and morpheme), in given social situations. Language function, therefore, implies varieties of language that are defined 
according to use. Halliday (1978) labeled language as a "social semiotic" in the sense that it evolves in a context and the environment in which people deploy language to serve communicative needs can shape its form and meaning. The analysis of the texts would demonstrate that J. P. Clark- Bekederemo's poetry under study is dense with figurations which not only preserve and project the expressive beauty of the works, but also help to capture intentions more vividly and produce desired meanings and effect on the audience or readers.

\section{BRIEF BIOGRAPHY OF THE POET}

Born December 6, 1933 in Kiagbodo in the Ijaw area of present-day Delta State of Nigeria, to Ijaw and Urhobo parents (His father was Ijaw and mother Urhobo), Johnson Pepper Clark-Bekederemo had his primary school at Okrika (1940-1948) and Jeremi (1948), before proceeding to Government College, Ughelli, for his secondary education (19481953). He attended the University of Ibadan between 1955 and 1960. At Ibadan, together with a handful of other writers, he played a prominent role in establishing Nigeria and the continent of Africa as one of the major centres of Literature in English in the twentieth century. Of his Ibadan years, Wren (1984) remarks that Clark-Bekederemo "showed the most precocious talent that West African literary history had yet seen." The poet has worked as an information officer, journalist, and University professor. Apart from his poetry, Clark-Bekederemo is also a frontline African dramatist and scholar. He has also written a novel (travelogue) America, their America(1964), which is an account of his sojourn in America as a Parvin fellow at Princeton University (1962-63)

\section{Contextual Issues IN THE Poetry}

That language and context are two inseparable phenomena is a fact that has been long standing and established (see Leech, 1983:13). Morley (1985: 4) points out that, "context serves to itemize those aspects of the situation which have a bearing on the form used". The critical point in that, context is an important aspect of language use. As we shall demonstrate in the analysis of the texts, the true meaning of a text can be thought of as a relationship between its linguistic elements and whatever contextual evidence is available for clarifying it. In J. P. Clark-Bekederemo's poetry, certain variables constitute the context of situation. These include: genre type, background experiences of the poet, socio-political realities, and subject-matter.

\section{TeXtual Analysis}

J.P. Clark-Bekederemo has been writing poetry for over fifty years now (1958-date). Therefore, the writer's oeuvre is so expansive that a study of this scope can not reflect all the published poems or titles. The analysis is, thus, based on poems that are purposively selected from A Decade of Tongues (1981, i.e. poems written between 1958 and 1968), State of the Union (1985), Mandela and other Poems (1988), A Lot from Paradise (1999), and Once Again a Child (2004). The titles cut across the three distinct phases of the author's career viz: early (1958-1968), later (1970-1988), and latest (1999-date), and thus, strike a temporal balance between the writer's old and new poetry. The analysis focuses on imagery, metaphorization, rhetorical operations, humour, and figures of sound, as these figurative devices are not only recurrent in the texts but are also stylistically strategic.

\section{A. Imagery and Symbolism}

According to Eyoh (1997), imagery is " ...a mental picture created through words and the imaginative faculty, manifesting itself in various figures of speech" (p.125). The scholar contends that, mental and imaginative faculties, as well as feeling are central to the study and efficacy of imagery in a work of art. Eyoh (1997) adds that, the concept is "... a traditional element of poetry, constituting an important stylistic tool in the hands of poets of all ages" (p.126). In J. P Clark-Bekederemo's poetry, this trait manifests abundantly. In "War Effort" (Once Again a Child), J.P. ClarkBekederemo admits that he is a "bush boy". In extending this submission, many of his poems are laden with rustic ecological imagery, which reflect the geographical, physical or socio-cultural background of the poet. In "My Grandmother Mojiriemu" (Once Again a Child), for instance, there is the deployment of plant symbolism in the following expressions: Perfect graft to her tree (line 6), her sap (line 7), climb all over her (line 9), for a fruit I always seemed to need (line $10 \& 11$ ). All these describe the poet persona's relationship with Mojiriemu - a woman with no child of her own but who provided shades and fruits for children of other wives. In other figurative expressions used in many of the other poems in the text, there is recurrent reference to things of rustic origin/background. Consider the objects of similes in the following excerpts from "A Night Act in the Day" (Once Again a Child), for instance

(1) A free display one afternoon...

Scattering like a handful

of cowry shells a priest cast

to reach some hidden truth.

(2) Placing her head on the ground

Her palms, her platter Then, like

A cross between bat and owl, her head

Of coven, as if from its depths... 
These references reflect the religious/metaphysical worldview of the poet's African origins.

In further depicting the rustic origin of his poems, it is pertinent to mention the regular aquatic imagery that characterize the poems. For purposes of illustration in this study, a look at "My Sister and Her Fish" (Once Again a Child), where the following imagistic word and larger expressions are found, is important:

(i) it was ebb tide in a creek (line 1)

(ii) ashore (line 5)

(iii) water weeds (line 5)

The title itself reminds the reader of the geographical origin of the poet where rivers are predominant and fishing the main occupation of the Ijaw people. The critical stylistics point to note here is that, in addition to the aesthetic qualities of these and some other figurative expressions in the poems, they further serve in indicating that the poems are not just products of imagination but that they are also largely a product of true experience.

\section{B. Metaphorization}

In the words of Halliday (1985), metaphor is "the variation in the use of words such that words have transferred meaning" (p.320). In most cases, metaphorical expressions are semantically odd and syntactically incongruent. Michael Short (1982) views semantic deviation as meaning relations which are logically inconsistent or paradoxical in some ways and also classifies metaphor as semantic deviation (see Ayeomoni, 2003). These attributes compel readers to think harder before arriving at their true meaning.

In "Of Sects and Fellowships" (State of the Union), there is the use of "tide", "souls' and "market place" as a metaphor of rottenness characteristic of Christianity in contemporary times, which also describe the tragedy of the people who fall victims of the rottenness and condemn religious merchandising respectively. The first three lines of the poem re-written as follows describe the metaphors:

\begin{tabular}{|l|l|}
\hline Original texts & Re-write texts \\
\hline There is a tide across the land & There is an unstable tide in the \\
\hline Unstable has turned souls away & Land which has turned souls away from \\
\hline From cathedrals to the market place & Cathedrals to the market place \\
\hline
\end{tabular}

The word "tide" suggests turbulence; "cathedral" is a holy place and "market place" is suggestive of a place where all sorts of things take place, mostly evil. The soul is a metaphor of innocent people who often fall victims of false prophecy and religious hypocrisy. The metaphors are reinforced by the mockery expression “... are full of men and women in direct contact with God". To further enhance the satire, unlikely or unusual matters are associated with the duties of false men of God: Lines $9-11$ of the poem suggest this and further describe the ignorance of the devotees of these religious sects. The lines are reproduced below:

...On any matters from queries

At work to sale of rice while pews

Only fill for weddings and death

Noticeable in the excerpt above is the use of the word "only". This expression pre-supposes that there are some other things the pews should be filled with. It suggests also that these other things are better than 'weddings' and 'death'. What these other things are depends on individual readers. The use of "figures" in place of people in the second line of the second rhetorical stanza is to reduce (and therefore condemn) false prophets to nothing:

What is there is a flaming candle

Upheld by figures in flowing gowns...

The indirectness in the use of "a book" in the fourth line of the second stanza is strategic. The choice of the expression instead of "Bible" is for the purpose of describing what the holy book has become in the hand of the devilish men who call themselves men of God. Quite paradoxically, some of these figures in flowing gowns cannot even read the book they are carrying about "cover to cover". The gullibility or quietude of the people is likened to that of sheep in the expression "Draw flocks to their immolation". The underlined word "flocks" describes the stupidity and docility (i.e as stupid and docile as sheep) of the clients of these business organizations that their organizers call churches. By using these various metaphors, J.P. Clark-Bekederemo is able to achieve what Soyinka achieves in his play The Trials of Brother Jero.

Also, in "Election Report" (State of the Union), Clark-Bekederemo uses "shadow" to be suggestive of calamities, evils, unrests, that are often the negative outcomes of the sort of election report, which the poem describes. The following lines drawn from the poem are relevant in this context:

It was not necessary really

To call on prophet or fortune-teller to see

The new shadow falling over the land.

In Once Again a Child, there is the transferred metaphor of tree and its shade as contained in the poem "My Grandmother Mojiriemu" (p. 7). In this poem, Clark-Bekederemo likens his grandmother to a tree, which offers him shade and provides him fruit he always seemed to need. These are metaphors of protection, love and care. The horticultural images in the choices of the words "Sap", "Fruit", "Grafts" accentuate this metaphor. All of them project Mojiriemu (the poet's grandmother) as a symbol of perfect and natural kindness. This becomes understandable when we 
reason, that "She gave birth to no child herself" but still allowed someone else's children to "climb all over her" and "running to her for shade". Nothing best describes the woman more than a tree. Ordinarily, trees do not say no to anybody that comes under them for shade.

\section{Rhetorical Operations}

In many of the poems, under study, J.P. Clark-Bekederemo enlists question strategy to purge certain feelings and impress on readers certain attitudes. Such questions are called rhetorical because they are not congruent types, which demand readers response(s); they are asked based on an implicit common assumption by the poet that readers (because they share his experience and have common socio-cultural background) would be able to read senses into them. An examination of a few instances of the use of this trope will suffice here.

In "Victoria Island" (State of the Union), a twelve-line poem, J.P. Clark-Bedekeremo expresses dissatisfaction over the scramble for and partitioning of the Victoria Island in Lagos and condemns how people were deceived to believe that the land was taken away from them and was being developed by public money in the interest of all. The poet uses the poem to expose one of the excesses of the rich, particularly, leaders in Nigeria. The land was originally owned by a family before the existence of Nigeria as a country. In the spirit of patriotism, they let it go to the government. Now, it has been turned to a place reserved for few individuals who squander millions of naira among themselves and their mistresses. This story is disheartening. The questions in the last line of the poem-"Why should the country not be sick?" coveys the moral of this poem and is capable of stimulating unpleasant reactions from readers. The question presupposes that as long as the sort of discrimination and cruelty described in the poem remain in our country, the country would continue to suffer ruin. This is certainly the brand of Art which communicates "... a call to battle, a summon to positive change..." (Oha, 1994). While the rhetorical question described in this poem is instigating and expository, the one in "Of Sects and Fellowships" (State of the Union) is sarcastic and demeaning. The question is one-stanza:

What is there in a flaming candle

Upheld by figures in flowing gowns,

Draws flocks to their immolation

Upon a bell and a book the best

Of them, shedding incense, cannot

Even read from cover to cover?

The question suggests implicitly that there is nothing in the flaming candle that fake preachers, prophets often burn and the bell they use to draw people and even the "Bible" for they themselves do not understand it (see lines $14 \& 15$ ). This kind of question serves to purge the feelings of annoyance and infect readers with such feelings. It can therefore be regarded as an affective strategy in Clark's poetry (see "An old man on Trial" (Mandela and Other Poems), "The Court Beyond" (A Lot from Paradise), "A Prayer" (A Lot from Paradise), "A Matter of Weight" (A Lot from Paradise) etc., for more examples on this strategy).

\section{Humour}

In many of the poems under study, J.P. Clark-Bekederemo demonstrates that poetry is not entirely a mentally sapping enterprise; it should also relate to life as closely as possible. Life is an admixture of pain and gain, happiness and sadness, laughter and weeping, etc. Though Sweeney (1979) averred that "Literature and art generally are images of life, not life itself" (p.3). genuine art should capture this contrast or essence. This viewpoint is corroborated by Elechi Amadi when he opined that "Man needs aesthetics and relaxation to keep him going.. He must be given the opportunity to look at himself and laugh and weep" (emphasis mine). As an art form, the poet knows that his work should not only carry or project the gruelling burdens of society and the attendant pain, but should also generate exciting feelings through the aesthetics of humour and fun. J.P. Clark-Bekederemo achieves this through the incorporation of poems that are amusing or humorous to his readers. As would be shown shortly, though these poems are funny, typical of the inherent wittiness of African humours, they impress on readers the need to do some mental calculation before comprehending their true senses.

In "What Did You Do to Me?" (A Lot from Paradise), for instance, readers are delighted by the funny question a woman addresses to a man, probably her husband. It is a funny account of what happens between them, which eventually leads to her pregnancy. The three-line poem is presented below:

What did you do to me that night,

Although we hardly touched?

I was drunk for days after.

Two words have been given meaning extension in the poem above. They include "touched" and "drunk". These imply "sexual engagement" and 'pregnant', respectively.

Similarly, this strategy is found in "You Want Your Man" (A Lot from Paradise), "A Man Will Come" (A Lot from Paradise), "Other Women" A Lot from Paradise etc. In "A Man Will Come", there is the extension of sexual matter described above. Using the third person narrative style, Clark-Bekederemo describes the sexual tricks of the African man on the woman. The poet personae is probably a woman who understands this tricks very well and deems it necessary to educate fellow women whom she addresses as "You" (i.e. the second person which, in this context includes herself) in the poem reproduced below: 
From time to time

A man will come

Crying to you with all

Your gifts about you

He will lean on your breast

And you will pat him on the head

Believing all he wants is milk

The last line of the poem above pre-supposes, "all he wants is not milk but other things". Though these other things are not textually conveyed, mature readers are expected to supply them. With this strategy, readers are involved in the creative task of including, filling in or inserting missing textual ideas. Words and expressions suggestive of humor in the poem include "from time to time", "crying", "lean", "pat", and "milk". They evoke laughter and generate some pleasure in readers (particularly male readers) who realize certainly that they have been "caught" (i.e. their tricks discovered) and would probably feel unruffled, for more tricks lie in their brains undiscovered.

Also, in "Where Do they all Go" (State of the Union), the big wigs in Nigerian government, particularly the corrupt ones, are ridiculed through the humorous expression "Ascend to thrones termites dispute". This expression describes the fate of the set of politicians "When by force or choice" (line 2), they leave their various exalted positions. The choice of the imagery of termites here is symbolic. In the Nigerian context, the king of termites is a miniature king. So, when somebody occupies an unimportant position and is proud about it, he is simply regarded as "the king of termites". On an extended level of interpretation, when we consider the fact that termites preserve a very small place for their kings in their mounds, we can imagine how small the thrones they dispute would be.

Through this humor, corrupt leaders (politicians in Nigeria) are warned against using their offices for accumulating wealth for, whether they like it or not, all would end. It also serves to ridicule the Nigerian politicians who are so power-thirsty that they go to any length to occupy (even unimportant) leadership positions.

\section{E. Figures of Sound}

According to Balogun (1996), figures of sound are "sound devices used by poets to reinforce meaning in poetry or to create auditory pleasure" (p. 356). The scholar adds that, these devices include alliteration, onomatopoeia, repetition, assonance, consonance, rhyme and retrain. J.P. Clark-Bekederemo is meticulous in the deployment of sounds in many of his poems under study. These sounds are such that generate musical delights in readers and are suggestive of the subject matter of the poems in which they are used. As would be shown shortly, many devices are used in generating musical quality in the poems under study. These include alliteration, pun and onomatopoeia as found, for example, in "The Leaders" (A Decade of Tongues), "Lost Rite" (Once Again a Child) and "Two Moods of Princeton" (A Decade of Tongues), respectively.

In "The Leader", there is the repetition of the voiceless alveolar stop / $\mathrm{k} /$ in line 4 . When read aloud, the expression" Cousin the killer of cows" generates a sort of musical pattern that is intriguing. This device is also noticeable in "There, ding dong ding" drawn from "Two Moods of Princeton". The /k/ and /d/ rhythms produced by the repetition of the letters underlined in the excerpts above delight the senses by producing auditory impacts on readers. This device thus serves to make readers "hear" the poem and not just "read" it. This is also the case with repetition of the approximant /w/ in "War Effort" (Once Again a Child) referred to earlier. In this poem, the /w/ sound is repeated in thirteen places. This relates systematically with the subject of war, which the poem evokes. The import of this strategy becomes clearer when it is viewed against the background that it is a one-stanza poem with just eleven lines.

In "Lost Rites" (Once Again a Child), J.P. Clark-Bekederemo plays on two homophonic words "rites" and "rights". The poem suggests that many rites of passage the poetic personae has gone through as a child, now give him the right to re-enter his hometown after his many years of flight around the world.

Many of the poems, particularly the early ones, are also wrapped in musical beauties through repetitive use of sounds at strategic points. J.P. Clark-Bekederemo targets mostly and explores the end point of his lines as in "Pub-song" ( $A$ Decade of Tongues), "Tide-wash" (A Decade of Tongues), "The water maid" (A Decade of Tongues) and "The year's first rain" (A Decade of Tongues) to mention just a few, for sound innovation. Our preoccupation shortly, is a practical demonstration of how sounds are used to load or equip the poems with meaning and aesthetic potentials through a thorough examination of some of them.

In "Tide-wash", for instance, we notice the deployment of sound to relate to the excited feelings, which the poem evokes. The poem gives account of a bath in the stream, involving the poet and some other people. This, no doubt, is a delightful experience though there is a sense of disappointment in the second stanza, where the poet indicates that they are "depleted" and 'exposed'. The delightful experience is conveyed by the deployment of voiced sounds at the end of every line of the poem. The eight-line poem has the following word ending:

Line 1: Stream

Line 2: Sun

Line 3: Fun

Line 4: Steam

Line 5: Never

Line 6: Sand 


\section{Line 7: Stand}

Line 8: Ever

It is noticeable that, the eight lines end with the sounds $/ \mathrm{m} /, / \mathrm{n} /, / \mathrm{n} /, / \mathrm{m} /, \partial /, / \mathrm{d} /, / \mathrm{d} / \mathrm{and} / \partial /$ respectively. This pattern is certainly strategic and cannot be taken for granted in interpreting the poem. For instance, they are sounds that are technically called voiced sound. With the exception of lines 5 and 8 which end with vowel $/ \partial /$, all other sounds are consonant sounds. These consonant sounds are in consonant with the mood of the poem suggesting it as that of firmness. Also, all the consonant sounds are stop consonants whose mechanism of production relates to the sudden end that the voyager's enjoyment suffers as the tide-wash depletes and exposes them (line 7 and 8) on the naked sand.

Similarly in "Pub-song", sounds are deployed for conveying the sort of excited rap and ecstasy typical of pub-songs. The eight-line poem has the following sound ending:

Line 1: /ei/ say

Line 2: /z/ bawds

Line 3: /z/ gourds.

Line 4: /ei/ day

Line $5: / \mathrm{t} /$ meant

Line $6: / \mathrm{n} /$ broken

Line $7: / \mathrm{n} /$ open

Line 8: /t/ repent

As could be noticed, this poem is similarly constructed with the one discussed above. Line 1 of each rhymes with line 4, the same with line 2 and 3, 5 and 8 and 6 and 7, respectively. This design is a pointer to the fact that the poems are deliberately constructed to yield that pattern. Also, in "The water maid", five pairs of sound rhythm are noticeable thus:

Line 1 and 2: /1/ whole and soul.

Line 3 and 4: /t/ blight and night.

Line 5 and 6: /i/ me and me

Line 7 and 8: $/ \partial /$ thunder and over

Line 9 and 10: /ai/ dry and die

(See also "The Year's First Rain", "Return of the Fishermen”, "The Outsider", etc.).

"Agbor Dancer" (A Decade of Tongues), a twenty-line poem and "The Imprisonment of Obatala", a sixteen-line poem reflect the following end-sounding patterns respectively:

\begin{tabular}{|c|c|c|c|}
\hline (a) & $/ \mathrm{m} /$ & $/ \mathrm{k} /$ & $/ \mathrm{t} /$ \\
\hline & $/ \mathrm{m} /$ & $/ \mathrm{k} /$ & $/ \mathrm{t} /$ \\
\hline & $1 /$ & $/ \mathrm{t} /$ & $/ \mathrm{s} /$ \\
\hline & $/ \mathrm{n} /$ & $/ \mathrm{t} /$ & $/ \mathrm{y} /$ \\
\hline & $/ \mathrm{n} /$ & $/ \mathrm{t} /$ & $/ \mathrm{D} /$ \\
\hline (b) & $/ \mathrm{s} /$ & $/ \mathrm{t} /$ & /s/ \\
\hline & /s/ & $/ \mathrm{m} /$ & $/ \mathrm{n} /$ \\
\hline & /s/ & $/ \mathrm{t} /$ & $/ \mathrm{s} /$ \\
\hline & $/ \mathrm{s} /$ & $/ \mathrm{m} /$ & $/ \mathrm{y} /$ \\
\hline & $/ \theta /$ & $/ \mathrm{k} /$ & $/ \mathrm{t} /$ \\
\hline & $/ \theta /$ & $/ \mathrm{k} /$ & $/ \mathrm{t} /$ \\
\hline
\end{tabular}

These poems are products of a creative mind, desperately questing for aesthetic pleasure in his art and having sufficient time, energy and drive (being a youth) to achieve this aim, as the poems are from his early works. We are convinced that the poet certainly spends much time before achieving the sort of artistic patterning shown in the analysis of the poems above.

Perhaps, it is expedient to mention that, this kind of deliberate and exquisite sound patterning noticeable in the early poems of J.P. Clark-Bekederemo is conspicuously missing in the later poems under study. Except in "War Effort" from Once Again a Child where the sound /w/ is repeated in 13 places, to relate to the subject of war which the poem discusses, the poems in A Lot from Paradise and Of Sleep and Old Age are certainly not as musical.

\section{CONCLUSION}

In this study, we have examined the use of figurative language to foreground aspects of meaning and achieve auditory pleasure in J.P. Clark-Bekederemo's poetry. The study reveals that figuration is a significant feature of poetry, and that the author has deliberately deployed this device to effectively encode the meaning of the texts under study and also achieve aesthetic value, in relation to context of situation and textual function. This implies that, the linguistic analyst of J.P. Clark-Bekederemo's poetry, and poetry in general, should not take figurative locutions for granted when interpreting the texts.

\section{REFERENCES}

[1] Adejare, O. (1992). Language and Style in Soyinka: A Systemic Textlinguistic Study of a Literary Idiolect. Ibadan: Heinemann. 
[2] Alo, M. (1995). Applied English Linguistics: An Introduction. Port-Harcourt: Aeddy Link.

[3] Alo, M. (1998). Style in Language and Communication. Port-Harcourt: Aeddy Link.

[4] Ayeomoni, N. (2003). "The Role of Stylistics in Literary Studies". In Oyeleye, L. \& Olateju, M. (eds.) Readings in Language and Literature. Ile-Ife: OAU Press Ltd.

[5] Babajide A.O. (2000). "Of Style and Stylistics”. In Babajide, A.O. (ed.) Studies in English Language. Ibadan: Enicrownfit Publishers.

[6] Balogun, F.O. (1996). "Literary Forms and Devices". In Longe, V. U. \& Ofuani, O. A. (eds.) English Language and Communication. Benin: NERA.

[7] Clark-Bekederemo, J.P. (1981). A Decade of Tongues. London: Longman.

[8] Clark-Bekederemo, J.P. (1985). State of the Union. Longman: Longman.

[9] Clark-Bekederemo, J.P. (1988). Mandela and other Poems. London: Longman.

[10] Clark-Bekederemo, J.P. (1999). A Lot from Paradise. Lagos: Malthouse Press.

[11] Clark-Bekederemo, J.P. (2004). Once Again a Child. Ibadan: Mosuro Publishers.

[12] Cluett, R. and Kampeas, R. (1979). Glossly Speaking. Toronto: Discourse Associates Ltd.

[13] Crystal, D. (1987). The Cambridge Encyclopedia of Language. Cambridge: CUP.

[14] Crystal, D. and Davy, D. (1969). Investigating English Style. London: Longman.

[15] Eyoh, L. (1997). J.P. Clark-Bekederemo's Poetry: A Study in Stylistic Criticism. An Unpublished Ph.D Thesis, University of Port-Harcourt.

[16] Halliday, M.A.K. (1970). "Language Structure and Language Function”. In Lyons, J. (ed.) New Horizons in Linguistics. Harmondswoth: Penguin Books.

[17] Halliday, M.A.K. (1971). "Linguistics and Literary Style". In An Inquiry into the Language of William Golding. London: Edward Arnold.

[18] Halliday, M.A.K. (1973). Explorations in the Functions of Language. London: Edward Arnold.

[19] Halliday, M.A.K. (1978). Language as a Social Semiotic: The Social Interpretation of Language and Meaning. London: Edward Arnold.

[20] Leech, G. (1969). A Linguistic Guide to English Poetry. London: Longman.

[21] Miller, R. and Currie, I. (1970). The Language of Poetry. London: Heinemann Books Ltd.

[22] Ofuani, O. (1987). A Stylistic Analysis of Okot P 'Bitek's Poetry. An Unpublished Ph.D. Thesis, University of Ibadan.

[23] Ogbulogo, C. (2005). Concepts in Semantics. Lagos: Sam Iroanusi Publications.

[24] Ogunsiji, A. (2000). "Introductory Semantics". In Babajide, A.O. (ed) Studies in English Language. Ibadan: Enicrownfit Publishers.

[25] Oha, O. (1994). The Language of War Situation: A Stylistic Study of Ojukwu's and Gowon's War Speeches. An Unpublished $\mathrm{Ph}$. D Thesis, University of Ibadan, Nigeria.

[26] Osakwe, M.I. (1992). The Language of Soyinka's Poetry: A Diatype of English. An Unpublished Ph.D Thesis, University of Ibadan.

[27] Osundare, N. (2003). Cautious Paths through the Bramble: A Critical Classification of Style Theories and Concepts. Ibadan: Hope Publishers.

[28] Sweeney, E. (1979). Another Country: The Land of Literature. Enugu: Fourth Dimension Publishers.

[29] Todorov, T. (1977). The Poetics of Prose. New York: University Press.

[30] Ushie, J. (2001). Many Voices, Many Visions: A Stylistic Study of 'New' Nigerian Poetry. An Unpublished Ph.D. Thesis, University of Ibadan.

[31] Waudaugh, R. (1986). An Introduction to Sociolinguistics. Oxford: Blackwell.

[32] Wellek, R. and Warren, A. (1977). The Language of Literature. London: Longman.

[33] Yeibo, E. (2011). "Patterns of Lexical Choices and Stylistic Function in J.P Chlark-Beederemo's Poetry.” In Ahmadi, A. (ed.) International Journal of English Linguistics. Toronto: Canadian Center of Science and Education.

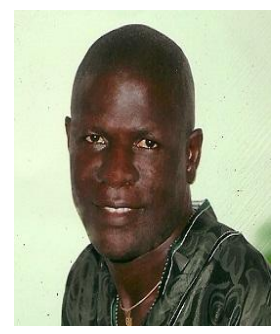

Ebi Yeibo was born in Bomadi, Delta State, Nigeria, on February 24, 1969. He obtained degrees in English from the Delta State University, Abraka (1996) and the University of Ibadan (2000), Nigeria, specializing in discourse analysis and stylistics.

He teaches stylistics, discourse analysis, applied linguistics, semantics and history of the English language at the Niger Delta University, Wilberforce Island, Bayelsa State, Nigeria, and has published scholarly papers on these areas in local and international journals. An award-winning poet, his published volumes of poetry include: Maiden Lines (Ibadan: Akol Press, 1997), A Song for Tomorrow (Ibadan: Kraftbooks Ltd, 2003), and The Forbidden Tongue (Ibadan: Kraftbooks Ltd, 2007).

Mr. Yeibo is a member of various professional and learned associations in Nigeria: Association of Nigerian Authors (ANA), Linguistic Association of Nigeria (LAN), and Nigerian Institute of Public Relations (NIPR). 